\title{
Editorial
}

Journal of Innate

Immunity

Published online: November 11, 2011

DOI: $\underline{10.1159 / 000334593}$

\section{Pancreatic Cancer Is Not Noble}

\author{
Michael T. Lotze \\ Hillman Cancer Center, University of Pittsburgh Cancer Institute, Pittsburgh, Pa., USA
}

For the last century, immunity was based on specificity, first, serological responses, and then over the last three decades, $\mathrm{T}$ cell immunity. We now recognize that innate immunity represents the solid core of immunity on which adaptive responses have been draped. This has most recently been acknowledged with the 2011 Nobel Prize in Physiology or Medicine being awarded to Bruce Beutler, Jules Hoffman and Ralph Steinman. As many of our readers know, our friend Dr. Ralph Steinman was afflicted by pancreatic cancer, working tirelessly for almost 5 years with immune therapies to alter his disease trajectory. Sadly, he never knew of the prize awarded to him, dying a scant few days before it was announced. We dedicate this issue of the Journal of Innate Immunity to his memory.

\section{Pathogen-Associated and Damage-Associated Molecular Pattern Molecules}

As posed in the last three decades, we would like to address the molecular pathways by which pathogen-associated molecular pattern molecules are recognized. In the setting of tissue injury including ischemia/reperfusion [ 1 , 2], arthritis [3], tissue damage [4] and cancer [5-9], damage-associated molecular pattern molecules (DAMPs) are released. We now recognize that as a biological response to starvation and metabolic stress, when ATP levels are low $[10,11]$, epithelial and stromal cells turn to autophagy [12-14]. Without a proper interaction with adjacent stroma, substrate provision to the tissues cannot be maintained. When this programmed survival pathway fails, epithelial cells die a necrotic death and release DAMPs. These include HMGB1 [1-9, 11-14], as reported by Nace et al. [15] and Berthelot et al. [16] in this issue of the Journal of Innate Immunity. Stromal cells respond by providing substrate to the metabolically stressed epithelial cells. We hypothesize that DAMPs perpetuate this shift in bioenergetics, promoting further autophagy [12-14]. The receptors that play a role, including RAGE (receptor for advanced glycation end products) [2, 14], as reported by Dessing et al. [17] in this issue, appear to be important for the response to low levels of HMGB1 but not to higher levels, where Toll-like receptor 2 and Toll-like receptor 4 (TLRs) play predominant roles. Other receptors include the NOD1/NALP-like receptors (NLRs) as put forward by Mason et al. [18], the RIG-I receptors (RLRs) and the AIM2-like DNA receptors (ALRs). Other proteins apart from HMGB1 play a role as DAMPs. In addition to heat shock factors (reviewed in part by Gally et al. [19] in this issue) and the S100 molecules (also reviewed in this issue, by Srikrishna [20]), extracellular proteins such as hyaluronan, heparin sulfate and fibronectin (Sofat et al. [21], in this issue) also play a role in alerting the innate immune response. Much clearly remains to be done to resolve the important role of these molecules in disease.

\section{KARGER \\ Fax +4161306 1234 \\ E-Mail karger@karger.ch}

www.karger.com (c) 2011 S. Karger AG, Basel

1662-811X/12/0041-0004\$38.00/0

Accessible online at:

www.karger.com/jin
Dr. Michael T. Lotze

G.27A Hillman Cancer Center

University of Pittsburgh Cancer Institute

Pittsburgh, PA 15213 (USA)

Tel. +1 412624 9375, E-Mail lotzemt@upmc.edu 


\section{Invitation to Heidelberg and the Fifth International DAMPs and Alarmins Symposium, 11-15 July, 2012}

This will be the 5th International DAMPs and Alarmins Symposium (iD\&As-V). It is to be held in Heidelberg on the 11-15 July, 2012, in conjunction with the
German Cancer Research Institute. The first symposium was in 2004 (Stockholm), followed by meetings in 2006 (Milano), 2008 (Pittsburgh) and 2010 (Helsinki). We would like to invite our readers to this meeting for a modern explication of DAMPs and their role in innate immunity.

\section{References}

${ }_{1}$ Tsung A, Sahai R, Tanaka H, Nakao A, Fink MP, Lotze MT, Yang H, Li J, Tracey KJ, Geller DA, Billiar TR: The nuclear factor HMGB1 mediates hepatic injury after murine liver ischemia-reperfusion. J Exp Med 2005;201: 1135-1143.

$\checkmark 2$ Zeng S, Feirt N, Goldstein M, Guarrera J, Ippagunta N, Ekong U, Dun H, Lu Y, Qu W, Schmidt AM, Emond JC: Blockade of receptor for advanced glycation end product (RAGE) attenuates ischemia and reperfusion injury to the liver in mice. Hepatology 2004; 39:422-432.

3 Ostberg T, Wahamaa H, Palmblad K, Ito N, Stridh P, Shoshan M, Lotze MT, Erlandsson $\mathrm{HH}$, Andersson U: Oxaliplatin retains HMGB1 intranuclearly and ameliorates collagen type II-induced arthritis. Arthritis Res Ther 2008; 10:R1.

-4 Tang D, Kang R, Zeh HJ 3rd, Lotze MT: High-mobility group box 1, oxidative stress, and disease. Antioxid Redox Signal 2011;14: 1315-1335.

$\checkmark 5$ Dong XE, Ito N, Lotze MT, Demarco RA, Popovic P, Shand SH, Watkins S, Winikoff S, Brown CK, Bartlett DL, Zeh HJ 3rd: High mobility group box I (HMGB1) release from tumor cells after treatment: implications for development of targeted chemoimmunotherapy. J Immunother 2007;30:596-606.

-6 Ito N, Demarco RA, Mailliard RB, Han J, Rabinowich H, Kalinski P, Stolz DB, Zeh HJ 3rd, Lotze MT: Cytolytic cells induce HMGB1 release from melanoma cell lines. J Leukoc Biol 2007;81:75-83.
7 Zeh HJ 3rd, Lotze MT: Addicted to death: invasive cancer and the immune response to unscheduled cell death. J Immunother 2005; 28:1-9.

$>8$ Tang D, Kang R, Zeh HJ 3rd, Lotze MT: High-mobility group box 1 and cancer. Biochim Biophys Acta 2010;1799:131-140.

$\checkmark 9$ Livesey KM, Tang D, Zeh HJ, Lotze MT: Not just nuclear proteins: 'novel' autophagy cancer treatment targets - p53 and HMGB1. Curr Opin Investig Drugs 2008;9:12591263.

10 Christofk HR, Vander Heiden MG, Harris $\mathrm{MH}$, Ramanathan A, Gerszten RE, Wei R, Fleming MD, Schreiber SL, Cantley LC: The M2 splice isoform of pyruvate kinase is important for cancer metabolism and tumour growth. Nature 2008;452:230-233.

-11 Tang D, Kang R, Livesey KM, Kroemer G, Billiar TR, Van Houten B, Zeh HJ 3rd, Lotze MT: High-mobility group box 1 is essential for mitochondrial quality control. Cell Metab 2011;13:701-711.

12 Tang D, Kang R, Livesey KM, Cheh CW, Farkas A, Loughran P, Hoppe G, Bianchi ME, Tracey KJ, Zeh HJ 3rd, Lotze MT: Endogenous HMGB1 regulates autophagy. J Cell Biol 2010;190:881-892.

13 Tang D, Kang R, Cheh CW, Livesey KM, Liang X, Schapiro NE, Benschop R, Sparvero LJ, Amoscato AA, Tracey KJ, Zeh HJ 3rd, Lotze MT: HMGB1 release and redox regulates autophagy and apoptosis in cancer cells. Oncogene 2010;29:5299-5310.

14 Kang R, Tang D, Schapiro NE, Livesey KM, Farkas A, Loughran P, Bierhaus A, Lotze MT, Zeh HJ 3rd: The receptor for advanced glycation end products (RAGE) sustains autophagy and limits apoptosis, promoting pancreatic tumor cell survival. Cell Death Differ 2010;17:666-676.
15 Nace G, Evankovich J, Eid R, Tsung A: Dendritic cells and damage-associated molecular patterns: Endogenous danger signals linking innate and adaptive immunity. J Innate Immun 2012;4:6-15.

16 Berthelot F, Fattoum L, Casulli S, Gozlan J, Maréchal V, Elbim C: The effect of HMGB1, a damage-associated molecular pattern molecule, on polymorphonuclear neutrophil migration depends on its concentration. J Innate Immun 2012;4:41-58.

17 Dessing MC, Pulskens WP, Teske GJ, Butter LM, van der Poll T, Yang H, Tracey KJ, Nawroth PP, Bierhaus A, Florquin S, Leemans JC: RAGE does not contribute to renal injury and damage upon ischemia/reperfusion-induced injury. J Innate Immun 2012; 4:80-85.

18 Mason DR, Beck PL, Muruve DA: Nucleotide-binding oligomerization domain-like receptors and inflammasomes in the pathogenesis of non-microbial inflammation and diseases. J Innate Immun 2012;4:16-30.

19 Gally F, Minor MN, Smith SK, Case SR, Chu HW: Heat shock factor 1 protects against lung Mycoplasma pneumoniae infection in mice. J Innate Immun 2012;4:59-68.

20 Srikrishna G: S100A8 and S100A9: New insights into their roles in malignancy. J Innate Immun 2012;4:31-40.

21 Sofat N, Robertson SD, Wait R: Fibronectin III 13-14 domains induce joint damage via Toll-like receptor 4 activation and synergize with interleukin-1 and tumour necrosis factor. J Innate Immun 2012;4:69-79. 